\title{
Discussion
}

\section{Nanotechnology in its Socio-economic Context}

\author{
Guillermo Foladori and Noela Invernizzi
}

\begin{abstract}
Nanotechnologies are commonly touted as instruments to be exploited for the benefit of developed, as well as for developing countries, and especially for alleviating the problems of the poor. Defenders of nanotechnology argue that it is possible to learn from experience, avoiding the errors made with past technologies. Precaution, however, should not slow down innovation, which is the key factor in solving many of the problems of the poor. Clearly the focus is on innovation, and finding a solution to the problems of the poor is just a mechanical consequence. But it is not necessary, and nor is it true, that the faster the technological path, the narrower the gap between rich and poor. Indeed, judging from past experience, the opposite has usually been shown to be the case. We put forward the argument that nanotechnologies, like any other type of technology, cannot be separated from the socio-economic and political context in which they are generated, commercialized and utilized. Considering the current context, it is highly likely that the nanotechnology revolution will help widen the gap between rich and poor in the world.
\end{abstract}

Key words: nanotechnology, nanotechnology and society, developing countries

In recent years, governments, scientists and international organizations have cast the capacity of nanotechnologies for improving the living conditions of the poor in an optimistic light. An example of this is the view of the Task Force on Science, Technology and Innovation of the U.N. Millennium Development Project (Juma \& Yee-Cheong, 2005: 70). The Canadian Joint Center for Bioethics (JCB) also holds the belief that nanotechnology can be used to help achieve five of the eight Millennium Development Goals (Salamanca-Buentello et al., 2005). The organizers of the conference for the North-South Dialogue on Nanotechnology: Challenges and Opportunities, hosted by the United Nations Industrial Development Organization in Trieste, Italy, put forward similar ideas (ICS-UNIDO, 2005). This optimistic viewpoint is based on the technical potential of nanotechnologies for application to the urgent needs of underprivi- 
leged populations.

\section{Nanotechnology and Poverty}

Two of the most serious problems in the developing world are the lack of drinking water and the scarcity of energy. Several relatively cheap nanotechnologies have already been developed to filter bacteria, viruses and other harmful pathogenic elements from the water to make it fit for drinking. This would provide a solution to the situation of the 1.1 billion people in the developing world who lack access to safe drinking water and have an immediate positive impact on the health of those people (see http:/ /www.nanowater.organization/). In the field of energy, with the help of nanotechnologies, it is possible to produce cheap photovoltaic films that can be laid across the roofs of buildings, or even solar film paint. There have also been important advances in carbon nanotubes for storing hydrogen and nanomaterials that make aero-generators lighter and more efficient (Holister, 2005). Nanotechnologies could also mean important benefits in other areas, such as the distribution of water in agriculture, more efficient delivery of drugs in the human body, environmental clean-ups using filters and catalysts.

The optimistic ideas do not omit the existence of risks in connection with nanotechnology. The most important risks are those to health and the environment as a result of technical problems. There are also ethical and legal implications. It is true that these risks could be bigger in developing countries, where rules and regulations tend to be less demanding and less rigorously enforced and monitored. Nevertheless, this opti- mistic train of thought concludes that these problems can be dealt with and solved in such a way that the benefits would be greater than any losses (Lux Research, 2005). Roco (2003), a spokesperson for the National Nanotechnology Initiative in the United States, suggests that through networks and the responsible action of researchers, the risks can be overcome and international forces can be harmonized. Nowadays, there is much legislation that requires studies into the social impacts of nanotechnologies. ${ }^{1}$

It seems that most of those who work on nanoscience and nanotechnology research, and many of the companies dedicated to the manufacture of nanomaterials and nanodevices, have a narrow technical vision of the relationship between society and technology, and believe that utilizing nanotechnologies to benefit the poor is merely a problem of political will and ethics.

\section{The Socio-economic and Political Restrictions on the Diffusion of Technologies}

The optimistic attitudes have been questioned by recent studies that have highlighted concern over the many possible impacts of nanotechnologies on human health and the environment (ETC Group, 2004); on population control (Mehta, 2002); on the lack of mechanisms for people to have the power of decision over new technologies (Sarewitz and Woodhouse, 2003); on the military implications (Altmann and Gubrud, 2004); on the regulations and legal matters (Bennett, 2004); and on the ethical implications of technologies that may even harness some of the capacities of the human body (Wolbring, 2002). 
Nevertheless, there is one area that has had almost no analysis: that of the indirect social and economic impacts of nanotechnologies due to the current socio-economic context. Nanotechnologies have come into a world in which wealth is highly concentrated and social differences are alarming. Over the past thirty years, the world has seen the rapid development of technologies, such as microelectronics, information technologies, biotechnologies and telecommunications. But this technological advancement, with its applications in almost every sector of production and the creation of new sectors, has not helped to bridge the poverty gap. The United Nations Development Program's Human Development Report found that inequality on a worldwide basis increased over the 1990s.

The era of globalization has been marked by dramatic advances in technology, trade and investment - and an impressive increase in prosperity. Gains in human development have been less impressive. Large parts of the developing world are being left behind. Human development gaps between rich and poor countries, already large, are widening. (UNDP, 2005: 19).

If this happened during the expansion of such powerful technologies, why would it be any different in the case of nanotechnologies? Defenders of nanotechnology claim that we can learn from past mistakes and avoid their happening again (Roco, 2003). But this argument, which could be valid for technical problems and for the conflicts that arise between science and society, is not valid for the problems that result from the economic context of the free market and enhanced globalization over the last twenty years.
The following indicators show the dramatic magnitude of the current social crisis:

The gap between rich and poor has widened since the nineties (UNDP, 2005: 19; Wade, 2001); life expectancy on average increased in the nineties, but the difference between countries has grown even more (World Bank, 2004a; 2004b); sixty million people are expected to migrate from sub-Saharan Africa in the coming decade due to desertification (UNCCD, 2004); the number of people living with HIV/AIDS has reached forty million, over $90 \%$ of which in Africa (ONUSIDA/OMS, 2003); two million people die of malaria every year, most of them children, and five thousand people die of tuberculosis every day (USAID, 2004; Medecins Sans Frontières, 2003).

The indicators cannot be attributed to technological development in and of itself. Market forces are mostly to blame for this situation, and it is possible to argue that in the context of a free market, any new technology leads to heightened concentration of wealth. The research into developing new drugs is an illustrative example. Pharmaceutical companies dedicate their investigations and research almost exclusively to the illnesses of rich nations (cancer, cardiovascular diseases, skin diseases), where $80 \%$ of the market is concentrated (North America, Japan and Europe). This contradiction of needs and scientific research is known as the 10/90 health gap, which means that only ten percent of funds are directed to researching the neglected diseases that are responsible for ninety percent of the world's burden of disease (Medecins Sans Frontières, 2001) because the poor do not represent a significant chunk of the market. The 
interest of companies is profit, whereas the poor are interested in satisfying their needs. In a world where the satisfaction of needs is subject to the market, there is a conflict of interests between poor consumers and producers. The conflict of interests is the main reason why any new technology only tends to benefit the rich and concentrate wealth.

The same also applies in the case of nanotechnologies. Most of the patents are from large corporations based in the United States (Regalado, 2004; Nordan et al., 2005). If there is a real intention to take nanotechnology laboratories to developing countries, there should be, for instance, a moratorium on nanotechnology patents. In collaboration with an international not-for-profit institute of technology transfer, this would help to train skilled workers in developing countries. But such measures are not up for discussion. It is claimed that without patents, there will be no significant profit, and without profit there will be no research. However, this argument is not valid in that nanotechnologies were born from subsidies from public funds, and until 2005 most financing came from public funding (NanoxChange, 2004). If it is agreed that in the mid- and long-term an innovation process without patents would slow down, it is fitting to ask: which is more important: the pace of innovation or the reduction of poverty?

Let us take the case of nanotechnology devices that purify water and photovoltaic films that capture energy, which are more clearly related to the reduction of poverty. The Center for Responsible Nanotechnology (CRN, undated) has suggested that these technologies can be produced for free for the poor by a molecular nanofactory project administered by an international body. They claim that the profits to be made from these selected devices would be insignificant when considering the whole set of nanotechnology products. There is also the proposal to foment PublicPrivate Partnerships (Salamanca Buentello et al., 2005²). But the experience of the Public-Private Partnerships that the World Health Organization subscribed to in the nineties for research and cheap distribution of medicine to poor countries was a similar idea, and its results were uncertain, doubtful or outright failures (Ollila, 2003; Yamey, $2001 ; 2002)$. To solve poverty effectively, public production and distribution is necessary, a process that avoids market laws, and this is not up for discussion.

Another foreseeable impact of nanotechnologies on poor countries and populations is employment (Meridian Institute, 2004; Mantel, 2003). Nanotechnologies will require only a small number of highly skilled workers, exactly the opposite of what the developing world has to offer. But, there is no ongoing discussion regarding the possibility of implementing mechanisms that will compensate for the increase in unemployment that will arise through the diffusion of nanotechnologies. Likewise, it is estimated that, owing to the development of molecular production, rich countries will be able to do without many natural resources that they currently import from developing nations (Meridian Institute, 2004; Mantel, 2003). Will the World Trade Organization, so in favor of the free market for developing nations, accept measures to compensate for the current imports from these nations, as they are expected to drop in the 


\section{future?}

At the moment, the need to analyze the potential risks of nanotechnologies is increasingly recognized. There are no reasons to think that a responsible policy for nanotechnology will ignore the risk analysis for poor countries. Nevertheless, conventional risk analyses cover only technical risks. The more fundamental impacts and implications of the diffusion of nantotechnologies for the poor, however, are due to their insertion in the current economic and social tendencies. These tendencies use technological innovation as a direct means of profit and the concentration of wealth. Solving the problems of the poor is, at best, an indirect political consequence.

\section{Notes}

1 In the USA, the law on the funding of nanotechnology specifies studies in Environmental, Legal, and Social concerns (U.S. OLPA, 2003) [“The bill also provides for a research program to identify the ethical, legal, environmental, and other societal concerns related to nanotechnology"].

2 Sallamanca-Buentello et al. (2005) propose a worldwide fund in the form of Public Private Partnership (Addressing Global Challenges Using Nanotechnology) to develop nanotechnologies to conserve energy, purify contaminated water etc., for developing countries.

\section{References}

Altmann, J. \& Gubrud, M.

2004 "Anticipating Military Nanotechnology". IEEE Technology and Society Magazine 23(4): 33-40.
Bennett, $\mathrm{M}$.

2004 "Does Existing Law Fail to Address Nanotechnoscience?" IEEE Technology and Society Magazine 23(4): 27-325.

CRN (Center for Responsible Nanotechnology)

nd "Finding a Solution that Balances Many Interests". http://www.crnano.org/ everyone.htm [Retrieved September $15,2005]$.

ETC Group

2004 "NanoParticles Shown to Cause Brain Damage." Organic Consumers Association. http://www.organicconsumers. org/foodsafety/nanobrain040504.cfm [Retrieved January 3, 2005].

Holister, P.

2005 "How Nanotechnology is Changing the Energy Equation.” NanoMarkets, LC. White Paper. March.

ICS-UNIDO

2005 Aide-Mémoire of the Expert Group Meeting on "North-South Dialogue on Nanotechnology: Challenges and Opportunities". http://www.ics.trieste.it/ Documents/Downloads/df2552.pdf [Retrieved September 13, 2005].

Juma, C. \& Yee-Cheong, L. (Eds.)

2005 Innovation: Applying Knowledge in Development. UN Millennium Project. Task Force on Science, Technology, and Innovation. London, Sterling, Va.: Earthscan. http://www.unmillenniumproject.org/ documents/Science-complete.pdf [Retrieved September 13, 2005].

2005 Nanotechnology's Environmental, Health, And Safety Risks Can Be AdMantell, K. dressed Responsibly Today. June 15.

2003 "Developing Nations 'Must Wise Up to Nanotechnology'. Science and Development Network, September 4. http:/ /www.scidev.net/ [Retrieved February 12, 2005].

Medecins Sans Frontières

2001 "Fatal Imbalance. The Crisis in Research and Development for Drugs for Neglected Diseases". Drugs for Neglected Diseases Working Group (DND). Geneva. 
2003 “Seven Million Die Each Year From Aids, Tb and Malaria. Most of These People Live in Developing Countries. Http://www.msf.org.au/advocacy/ Mehta, M. globalfund/ [retrieved August 16, 2004].

2002 "Privacy vs. Surveillance. How to Avoid a Nano-panoptic Future". Canadian Chemical News, Nov-Dec: 31-33.

Meridian Institute

2005 "Nanotechnology and the Poor: Opportunities and Risks." www. nanoandthepoor. org [Retrieved September 13, 2005].

NanoxChange

2004 The Nanotech Report 2004. Key Findings. Lux Research Releases, http:// www.nanoxchange.com/ [Retrieved February 12, 2005].

Nordan, M., Sullivan, T., Lackner, D.,

Holman, M., Mamikunjan, V. \& Csaba, N.

2005 "Nanotechnology:Where Does the U.S. Stand?" Lux Research, NP-T-01-001. June 29.

Ollila, E.

2003 "Health-related Public-private Partnerships and the United Nations". In Deacon, B., Ollila, E., Koivusato, M., \& Stubbs, P., Global Social Governance. Ministry for Foreign Affairs of Finland. Department for International Development Cooperation. www.gaspp.org/ publications/ [Retrieved October 04, 2003].

ONUSIDA/OMS (United Nations Joint Program on HIV-AIDS \& World Health Organization)

2003 La Situación Mundial del SIDA. World Health Organization, Geneve.

Regalado, A.

2004 "Nanotechnology Patents Surge". The Wall Street Journal June 18: Al.

Roco, M.

2003 "Broader Societal Issues of Nanotechnology". Journal of Nanoparticle Research 5: 181-189.

Salamanca-Buentello, F., Persad, D.L., Court, E.B., Martin, D.K., Daar, A.S., Singer, P.

2005 "Nanotechnology and the Developing World". PLoS Medicine 2(5), May. http:/ /medicine.plosjournals.org/ [Retrieved May 20, 2005].
Sarewitz, D., \& Woodhouse, E.

2003 "Small is Powerful." Pp. 63-83 in Sarewitz, D., Lightman, A. \& Desser, C., Living with the Genie: Essays on Technology and the Quest for Human Mastery. Washington D.F: Island Press.

U.S. OLPA

$200321^{\text {st }}$ Century Nanotechnology Research and Development Act. Session I - P.L. 108-153. [Retrieved September 14" http://olpa.od.nih.gov/actions/public/108session $1 /$ pl108-153.asp [Retrieved September 14, 2005].

\section{UNCCD}

2004 “Ten Years On: One Decade of Combat Desertification. UN Marks World Day to Combat Desertification". Observances worldwide on June 17, 2004. http://www.unccd.int/publicinfo/ UNDP menu.php [Retrieved August 16, 2004] .

2005 Human Development Report. http:// hdr.undp.org/ [Retrieved September USAID 13, 2005].

2004 "The Global Burden of Tuberculosis (TB)". "http://www.usaid.gov/our_ work/global_health/id/tuberculosis/ burden.html" http://www.usaid.gov/ our_work/global_health/id/tuberculosis/burden.html [Retrieved August 16, 2004].

Wade, R.H.

2001 "The Rising Inequality ofWorld Income Distribution". Finance and Development 38(4).

Wolbring, G.

2002 Science and Technology and the Triple D (Diseases, Disability, Defect). In Roco, M.C. \& Bainbridge, W.S. (eds.), Converging Technologies for Improving Human Performance. Nanotechnology, Biotechnology, Information Technology and Cognitive Science. NSF/DOCsponsored report. Arlington: National Science Foundation. http://www.wtec. org/ConvergingTechnologies/ [Retrieved March 14, 2005]. 
World Bank

2004a PovertyNet. Social Indicators, 2004. http://www.worldbank.org/ [Retrieved August 16, 2004].

2004b "Global Poverty Down By Half Since 1981 But Progress Uneven As Economic Growth Eludes Many Countries". News Release No: 2004/309/S. http://web. worldbank.org/ [Retrieved August 16, 2004].

Yamey, G.

2001 "Global Campaign to Eradicate Malaria. British Medical Journal 322: 11911192.

2002 "WHO in 2002. Faltering Steps Towards Partnerships”. British Medical Journal 325: 1236-1240.

Guillermo Foladori \&

Noela Invernizzi

Universidad Autónoma de Zacatecas

México

fola@estudiosdeldesarrollo.net 